\title{
Solar Energy Modelling over a Residential Community in the City of Calgary, Alberta, Canada
}

\author{
Quazi K. Hassan, ${ }^{1}$ K. Mahmud Rahman, ${ }^{1}$ Anis S. Haque, ${ }^{1}$ and Ahad Ali ${ }^{2}$ \\ ${ }^{1}$ Schulich School of Engineering, University of Calgary, 2500 University Dr. NW Calgary, AB, Canada T2N 1N4 \\ ${ }^{2}$ A. Leon Linton Department of Mechanical Engineering, Lawrence Technological University, 21000 W Ten Mile Road, \\ Southfield, MI 48075, USA
}

Correspondence should be addressed to Quazi K. Hassan, qhassan@ucalgary.ca

Received 2 February 2011; Revised 18 March 2011; Accepted 21 March 2011

Academic Editor: Ugo Mazzucato

Copyright ( 92011 Quazi K. Hassan et al. This is an open access article distributed under the Creative Commons Attribution License, which permits unrestricted use, distribution, and reproduction in any medium, provided the original work is properly cited.

Solar energy is an abundant source of renewable/sustainable energy, which has an enormous potential in reducing the foot print of the greenhouse gases. In this paper, we presented a modelling framework of estimating solar energy over a portion of a residential community of Sandstone in the northwest of Calgary, Canada. We calculated the actual daily incident solar radiation as a function of latitude, day of year, and possible day light hours; and also employed high-resolution remote sensing images to calculate the effective roof area for installing photovoltaic cells. Strong relationships $\left(r^{2}: 0.91-0.98\right)$ were observed between the ground-based measurements and the modelled actual incident solar radiation at three test locations in Alberta. Over the portion of Sandstone, $\sim 1706.49 \mathrm{~m}^{2}$ roof surface area was suitable for potential installation of the photovoltaic cells. With $15 \%$ efficient photovoltaic cells, our analysis revealed that we might be able to produce significant amount (i.e., in the range of $\sim 67-100 \%$ ) of electrical energy needs of the residents of Sandstone community during the period between April and September.

\section{Introduction}

Fossil fuels (i.e., coal, oil, and natural gas among other) have been satisfying most of our energy needs ( $\sim 79 \%$ of the global energy consumption in 2006; [1]) over the decades. However, there are two limiting factors in using fossil fuels: (i) they are not renewable, thus unable to support the growth of our energy demands in coming decades to centuries; and (ii) release enormous amount of greenhouse gases into the atmosphere, which are largely responsible for the rapid global warming [2]. Thus, it is important for us to study renewable energy sources and its sustainability [3-6], as these sources are (i) able to support our energy needs; and (ii) effective in reducing the emission of greenhouse gases. The potentials of these renewable energy sources (that include: solar, wind, bioenergy among others) have undergone extensive research across the world (e.g., [7-12]). Recently, researchers indicated two facts regarding the potential of renewable energy sources to support (i) equivalent electrical energy needs for the countries of USA and New Zealand by 2020 [13], and (ii) also all purpose energy needs at global scale by 2030 [14]. In this paper, we intend to model potential solar energy for supporting electrical energy needs for residential uses, which already has proven to be a sustainable energy source [15-19].

In modelling solar energy over built-up areas, a number of factors need to be understood, such as, (i) the calculation of potential/actual incident solar radiation $[20,21]$, (ii) the technology available to convert the incident solar radiation into energy $[21,22]$, and (iii) the suitable surface area within a built-up area that are exposed to the sun to the greatest extent. In most of the instances, the modelling of the daily incident solar radiation is described in the literature as a function of latitude, day of year, and possible daylight hours [20-24]. Photovoltaic cells are most commonly used in producing electric energy from solar radiation. In converting the available solar radiation into electrical energy, photovoltaic cells are most commonly used technological advancements [20, 22, 25]. In Canadian context, the total installed capacity of photovoltaic cells has been increased by $211 \%$ to $\sim 102 \mathrm{MW}$ in 2009 from 2008 [26]. In terms of 


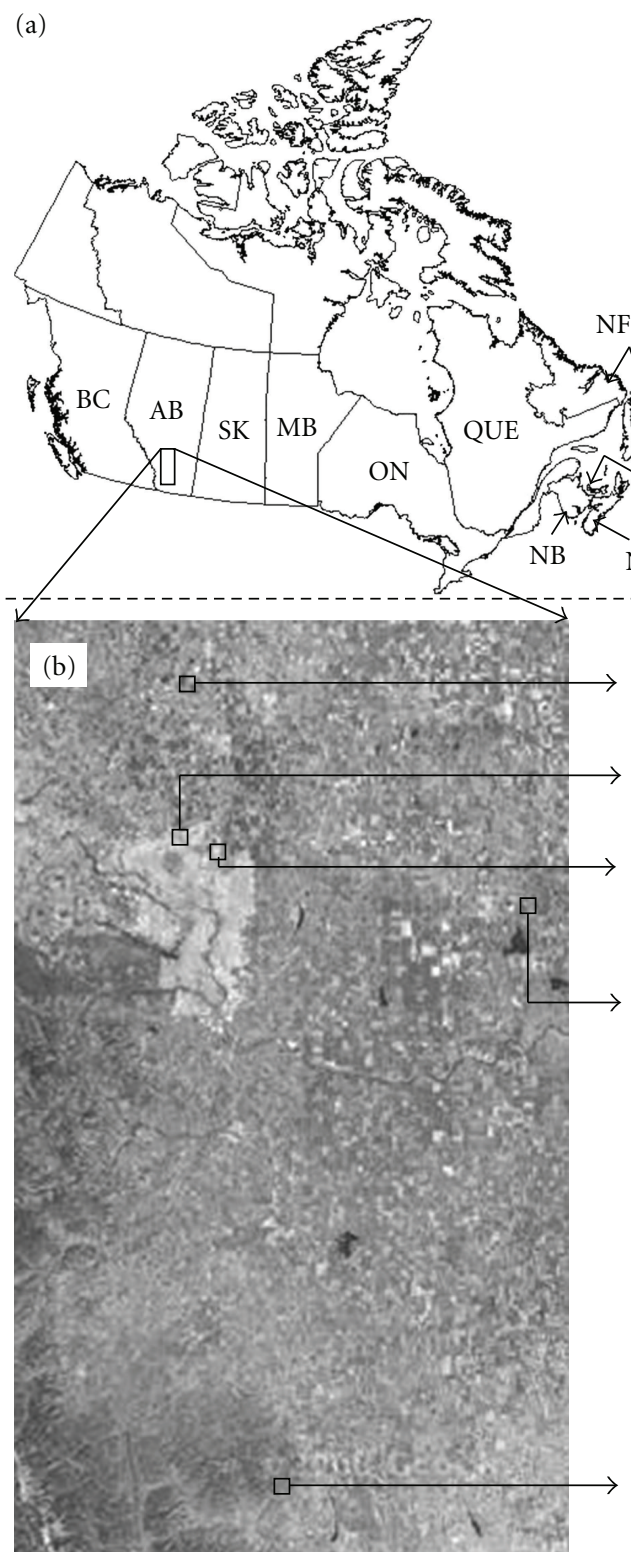

NFLD: Newfoundland and
Labrador

PEI: Price Edward Island

NS: Nova Scotia

NB: New Brunswick

QUE: Quebec

ON: Ontario

MB: Manitoba

SK: Saskatchewan

AB: Alberta

BC: British Columbia

NS

\section{Neir AEDM \\ (lat: $51^{\circ} 22^{\prime} \mathrm{N}$ : long; $114^{\circ} 6^{\prime} \mathrm{W}$ ) \\ Sandstone}

(lat: $51^{\circ} 8^{\prime} 29^{\prime \prime} \mathrm{N}$; long: $114^{\circ} 6^{\prime} 27^{\prime \prime} \mathrm{W}$ )

Calgary Int. Airport

(lat: $51^{\circ} 6^{\prime} 50^{\prime \prime} \mathrm{N}$; long: $114^{\circ} 1^{\prime} 13^{\prime \prime} \mathrm{W}$ )

Strathmore IMCIN

(lat: $51^{\circ} 2^{\prime} 19^{\prime \prime} \mathrm{N}$; long: $113^{\circ} 17^{\prime} 23^{\prime \prime} \mathrm{W}$ )

FIgURE 1: Location of: (a) the ten provinces in Canada; and (b) three sites (Neir AEDM, Strathmore IMCIN, and Stavely AAFC) in the province of Alberta, where the incident solar radiation regimes were modeled and validated and also the portion of the residential community of "Sandstone," where the simulation of the solar energy was conducted.

expanding the market of photovoltaic cells, Canada observes a consistent growth for the period of 1993-2009 with an annual increment of $\sim 22 \%$ [26]. These facts indicate that people are quite keen in harvesting solar energy. In calculating the suitable area for installing photovoltaic cells, remote sensing images can be an excellent data source, which are already a proven technology in extracting/delineating spatial information of interest $[27,28]$. It is the case as these provide an aerial view that is critical in determining the exposed surface area for installing photovoltaic cells (see Section 3.2 for more details).

In this paper, our objectives are to: (i) predict and validate the actual incident solar radiation at three locations (i.e., Neir Alberta Environment Drought Monitoring station (AEDM),
Strathmore Irrigation Management Climate Information Network station (IMCIN), and Stavely Agriculture and AgriFood Canada (AAFC); see Figure 1 for more details) in the Canadian Province of Alberta; (ii) calculate the effective roof area suitable for harvesting the greatest amount of incident solar radiation over the portion of "Sandstone" residential community in the city of Calgary (see Figure 1(b) for location information); and (iii) simulate the amount of equivalent electrical energy over the portion of Sandstone community.

\section{Study Area and Data Requirements}

In modelling solar energy, we considered a portion of Sandstone residential community with a size of approximately 


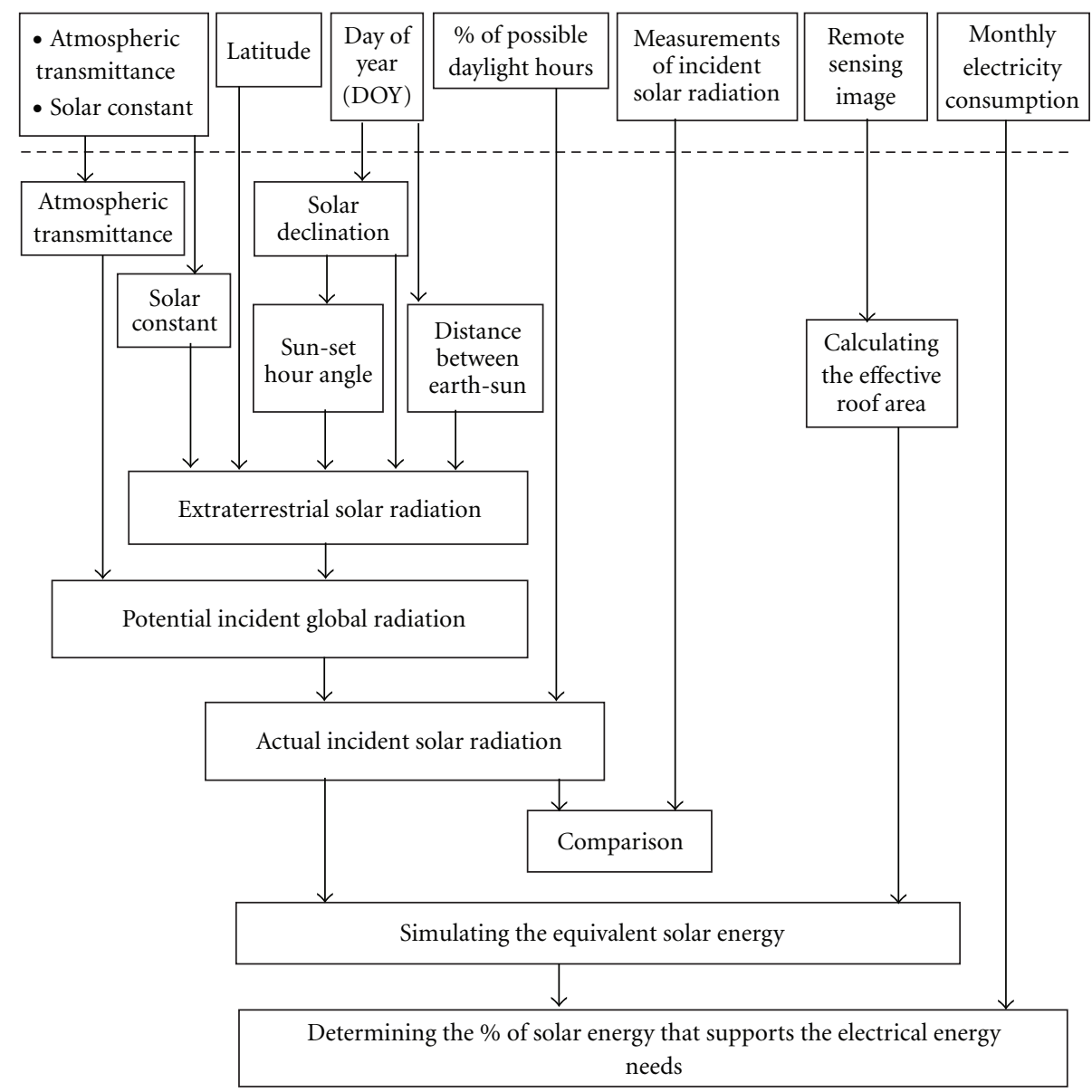

FIGURE 2: Schematic diagram of the steps employed in this study for modelling solar energy over the portion of Sandstone community in northwest of Calgary in the Canadian Province of Alberta.

$170 \mathrm{~m} \times 250 \mathrm{~m}$ (i.e., centered on the lat: $51^{\circ} 8^{\prime} 29^{\prime \prime} \mathrm{N}$; long: $114^{\circ} 6^{\prime} 27^{\prime \prime}$; see Figure 1(b)). In an average, the Calgary region experiences a relatively high sunshine hours (i.e., 2400 hour per annum; Environment Canada, available at: http://www.weatheroffice.gc.ca/canada_e.html. Accessed 18 March 2010) in comparison to other regions in the country. As there were no ground-based measurements of daily incident solar radiation data available near the study area, we opted to employ such measurements from three different locations, namely, Neir AEDM, Strathmore IMCIN, and Stavely AAFC. These three stations were within approximately $100 \mathrm{~km}$ radius of the study location (see Figure $1(\mathrm{~b})$ ), where measured radiation data was available. These data were made available by the Alberta Department of Agriculture and Rural Development for the period of 2007-2009 (AgroClimate Information Service, available at: http://www .agric.gov.ab.ca/app116/stationview.jsp. Accessed 18 March 2010). These ground-based measurements were used in validating the solar radiation model. We also used monthly average bright sunshine hours (in \% of possible daylight hours) for the period 1971-2000 at the Calgary International Airport (i.e., situated $\sim 9 \mathrm{~km}$ west of the study site of Sandstone community; see Figure 1(b)) available from Environment Canada. These data were used to transform the po- tential incident solar radiation to its actual amount. As these data were not available at the three locations where the ground-based measurements were available, we assumed that the bright sunshine hours would be applicable over those locations because of their proximity to each other. We also used high spatial resolution remote sensing data (i.e., QuickBird) in calculating the effective roof area that was exposed to the sun to the greatest extent. In addition, we obtained a monthly average electricity consumption data of the houses located in our study area (Association of Sandpoint Townhome Community, Personal Communication).

\section{Methods}

Figure 2 shows a schematic diagram of the processes involved in this study. It consisted of the following three major components: (i) modelling of actual incident solar radiation; (ii) calculating the effective roof area; and (iii) simulating the equivalent solar energy. Brief descriptions of all these components are provided in the following subsections.

3.1. Modelling of Actual Incident Solar Radiation. The spatio-temporal variability in actual incident solar radiation 
depends mostly on a number of factors: (i) latitude, (ii) day of year (DOY), (iii) configuration of local terrain, and (iv) atmospheric transmittance [29]. Note that the earth surface may receive a maximum of $75 \%$ of the incident solar radiation strikes on top of the earth's atmosphere due to the loss in the atmosphere (in other words, atmospheric transmittance) under cloud-free clear-sky conditions [23]. In calculating the daily solar radiation on a horizontal plane at a location of interest, we used the following equations $[19,21,23,24]$ :

$$
\begin{gathered}
R_{\text {daily }}=\left(a+b \frac{n}{N}\right) * R_{\text {daily-ex }} \\
R_{\text {daily-ex }}=\frac{1}{\pi} E_{0} d_{r}\left[\omega_{s} \sin (\phi) \sin (\delta)+\cos (\phi) \cos (\delta) \sin \left(\omega_{s}\right)\right] \\
d_{r}=1+0.033 \cos \left(\frac{2 \pi}{365} \mathrm{DOY}\right), \\
\delta=0.409 \sin \left(\frac{2 \pi}{365} \mathrm{DOY}-1.39\right), \\
\text { Radians }=\frac{\pi}{180}[\text { decimal degrees }], \\
\omega_{s}=\arccos [-\tan (\phi) \tan (\delta)],
\end{gathered}
$$

where $R_{\text {daily }}$ and $R_{\text {daily-ex }}$ are the daily and extraterrestrial incident radiation, respectively $\left[\mathrm{W} \cdot \mathrm{m}^{-2}\right], a(=0.25)$ and $b$ $(=0.50)$ are the Angstrom values [dimensionless] [30], $n / N$ is the $\%$ of possible daylight hours (i.e., form of bright sunshine hours) [dimensionless], $E_{0}$ is the solar constant = $1353 \mathrm{~W} \cdot \mathrm{m}^{-2}$ [5], $d_{r}$ is the inverse relative distance between earth-sun, $\delta$ is the solar declination angle [radians], $\phi$ is the latitude [radians], $\omega_{s}$ is the sunset hour angle [radians], and DOY is the number of the day in the year between 1 ( 1 January) and 365 or 366 (31 December).

Equation (1) can be used to calculate the daily potential incident solar radiation $\left(R_{\text {daily-potential }}, \mathrm{W} \cdot \mathrm{m}^{-2}\right)$ if we consider the value of $n / N(=1)$ and take the following form:

$$
R_{\text {daily-potential }}=0.75 * R_{\text {daily-ex }} .
$$

3.2. Calculating the Effective Roof Area. We used ISO-data clustering technique to classify the remote sensing image into two classes: (i) roof area; and (ii) others. We then identified the south and south-west facing roof surfaces and excluded the rest of the roof areas from further consideration as shown in Figure 3. Because, the particular-facing surfaces were able to harvest the greatest amount of incident solar radiation in the northern hemisphere. It revealed that approximately $1706.49 \mathrm{~m}^{2}$ area were suitable for installing photovoltaic cells out of a total of $\sim 8051 \mathrm{~m}^{2}$ available roof surface. To verify the calculated effective roof area, we conducted field verification to ensure that these roof tops were not occupied for other utilities.

3.3. Simulating the Equivalent Solar Energy over Sandstone. Once validating the daily solar radiation model and performing the calculation of the effective roof area as outlined earlier

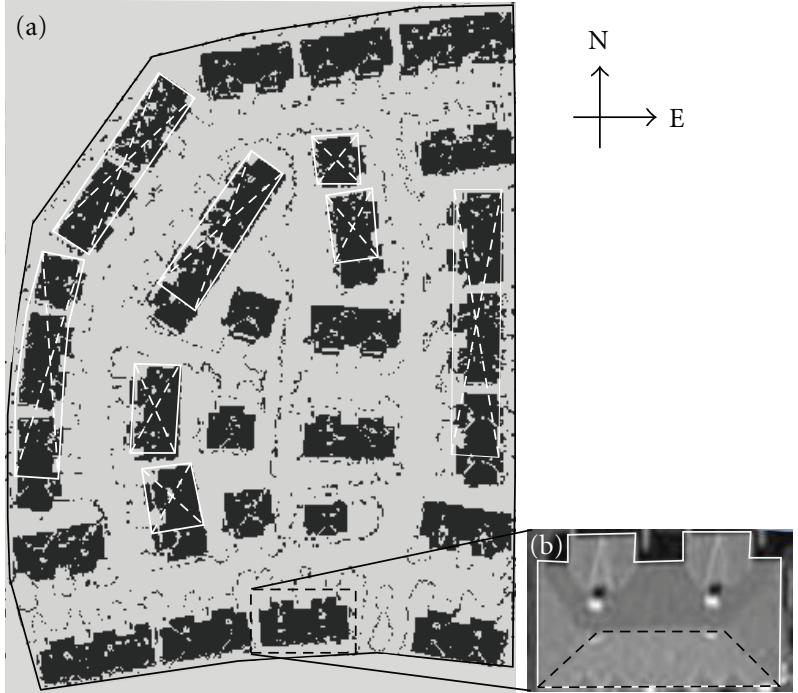

- Roof surface

Others

FIgure 3: (a) Classification of the remote sensing image into two classes of (i) roof surface; and (ii) others within the area of interest denoted by black polygon. The roof surfaces under the white crosses with the white rectangles were excluded from further consideration (as there were not oriented to either south or south-west directions). (b) an extended view of a roof surface, where the dotted black boxed area was only considered as suitable for harvesting the greatest amount of incident solar radiation.

(see Sections 3.1 and 3.2), we implemented the daily actual solar radiation over the Sandstone community. The annual amount of solar energy was estimated using the following expressions:

$$
\begin{aligned}
E_{\text {solar }} & =\sum_{i=1}^{365 \text { or } 366} R_{\text {daily }}(i) * A_{\text {effective-roof }} * E_{\mathrm{PV}}\left[\mathrm{W} \cdot \text { day }^{-1}\right] \\
& =\sum_{i=1}^{365 \text { or } 366} R_{\text {daily }}(i) * A_{\text {effective-roof }} * E_{\mathrm{PV}} * \frac{24}{1000}[\mathrm{KW} \cdot \mathrm{h}],
\end{aligned}
$$

where $E_{\text {solar }}$ is the accumulated solar energy over the entire year [in $\mathrm{KW} \cdot \mathrm{h}], A_{\text {effective-roof }}$ is the effective roof area $\left(\approx 1706.49 \mathrm{~m}^{2}\right.$ in this study), $E_{\mathrm{PV}}$ is the efficiency of the photovoltaic cells in converting solar radiation into energy ( $\approx 15 \%$ in this study). Note that the efficiency of the photovoltaic cells might vary in the range of $11-15 \%$ in general [31].

\section{Results and Discussion}

Figure 4 shows a comparison between the daily potential (using (7)) and ground-based measurements of incident solar radiation as a function of DOY. The intent was to observe how the envelope of the modelled values agreed with 


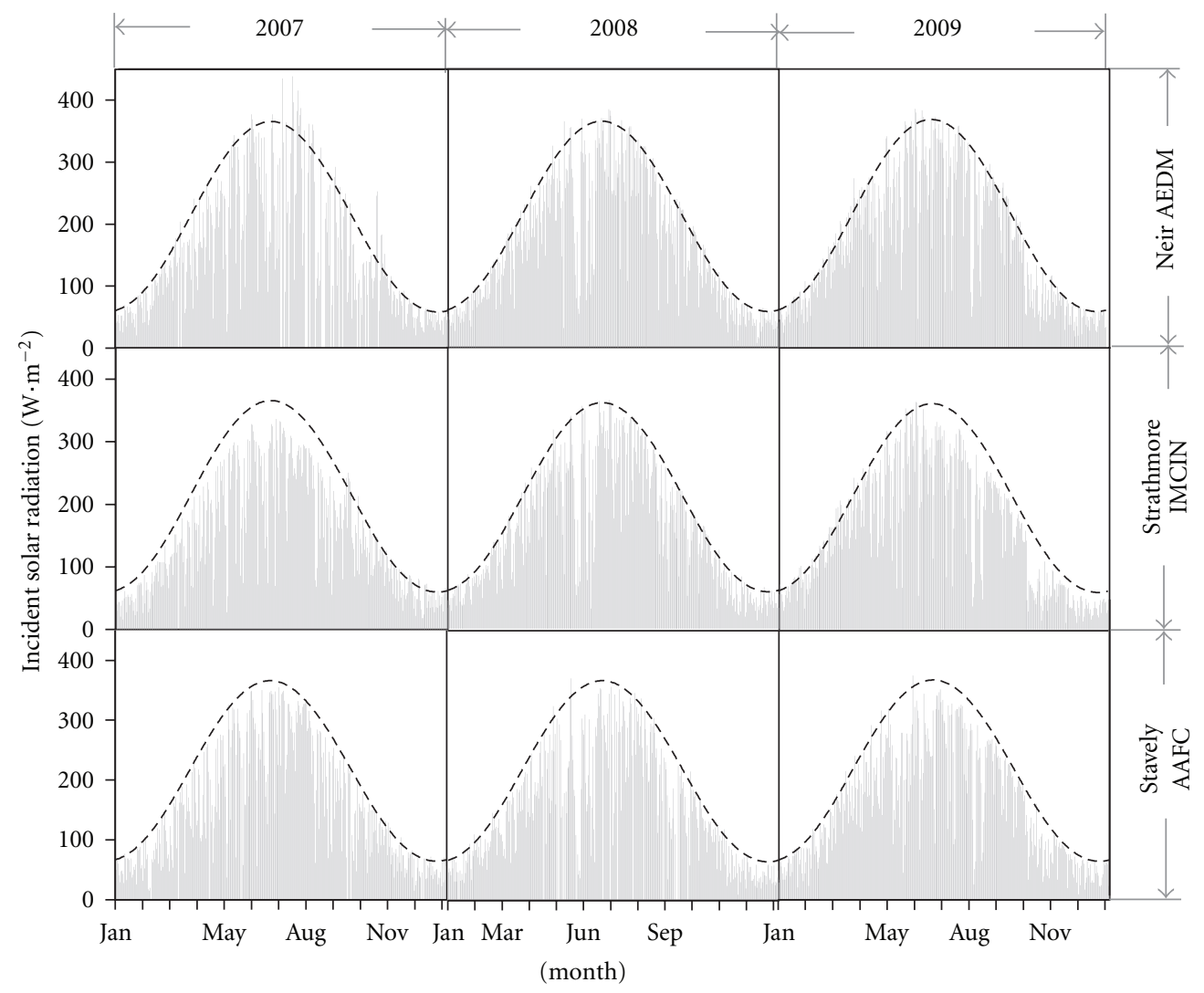

FIGURE 4: Comparison between modelled daily potential (black dashed lines) and ground-based measurements (gray vertical lines) of incident solar radiation at the locations of Neir AEDM, Strathmore IMCIN, and Stavely AAFC for the period of 2007-2009.

the measured ones. It revealed that the modelled values coincided quite well with the measured values during so many days. It might be associated with the fact that during those days, the sky was cloud-free, thus the actual and potential incident solar radiation was the same [32]. On the other hand, the relatively low measured values with compared to the modelled ones were related to the amount of cloud and other particles; those blocked the incoming solar radiation. In some instances, we observed that the measured values exceeded the modelled ones (e.g., at Neir AEDM in 2007). It might be associated with the higher amount of solar radiation passing through the atmosphere (i.e., greater than $75 \%$ of the atmospheric transmittance). In other instances, the relatively larger gaps between the measured and modelled values were also observed (e.g., at Strathmore IMCIN in 2007 in particular). In such case, the amount of atmospheric transmittance might be relative less. However, the incorporation of the interannual variations in atmospheric transmittance would be relatively complicated in this sort of modelling exercise, as it required the ground based measurements at the location of interest. Note that at the area of interest (i.e., Sandstone), we did not have any such ground-based measurements.

Figure 5 shows relationships between the measured and modelled values of the actual incident solar radiation accumulated at monthly scale. It revealed strong relations (i.e., $r^{2}$-values in the range of $\left.0.91-0.98\right)$ between them. Similar relations were also found in the literature (e.g., [29, 33]). The coefficients of the regression lines (i.e., slopes and intercepts in the range of $0.88-1.08$ and $0.05-0.36 \mathrm{KW}$, respectively) were also found to be in the reasonable bound. A relatively small discrepancies between the modelled and measured values were due to the fact that we employed the "\% of possible daylight hours" acquired at the Calgary International Airport (i.e., situated not exactly at the locations, where we performed this modelling exercise). However, the rationale of employing such data was to find how the longterm monthly average values (i.e., during the period 19712000) could capture the dynamics of actual incident solar radiation regimes over a region during a particular year of interest. Thus we concluded the solar radiation model would perform well in the Southern Alberta region.

Finally, we implemented the solar radiation model and used (8) to model the annual amount of solar energy over the portion of Sandstone (see Figure 3 for the suitable roof tops, where the photovoltaic cells might be installed). Our calculations revealed that we might be able to harvest $\sim 322408 \mathrm{KWh}$ per annum solar energy (see Figure 6 for more details). On the other hand, the approximated electrical energy consumption over there was found to be $\sim 523200 \mathrm{KWh}$ per annum (i.e., $400 \mathrm{KWh}$ per month per unit home, with a total of 109 units in the complex). Thus, upon installing 15\% efficient photovoltaic cells over an area of $1706.49 \mathrm{~m}^{2}$, we might obtain the following "\%" of the electrical energy demands: 


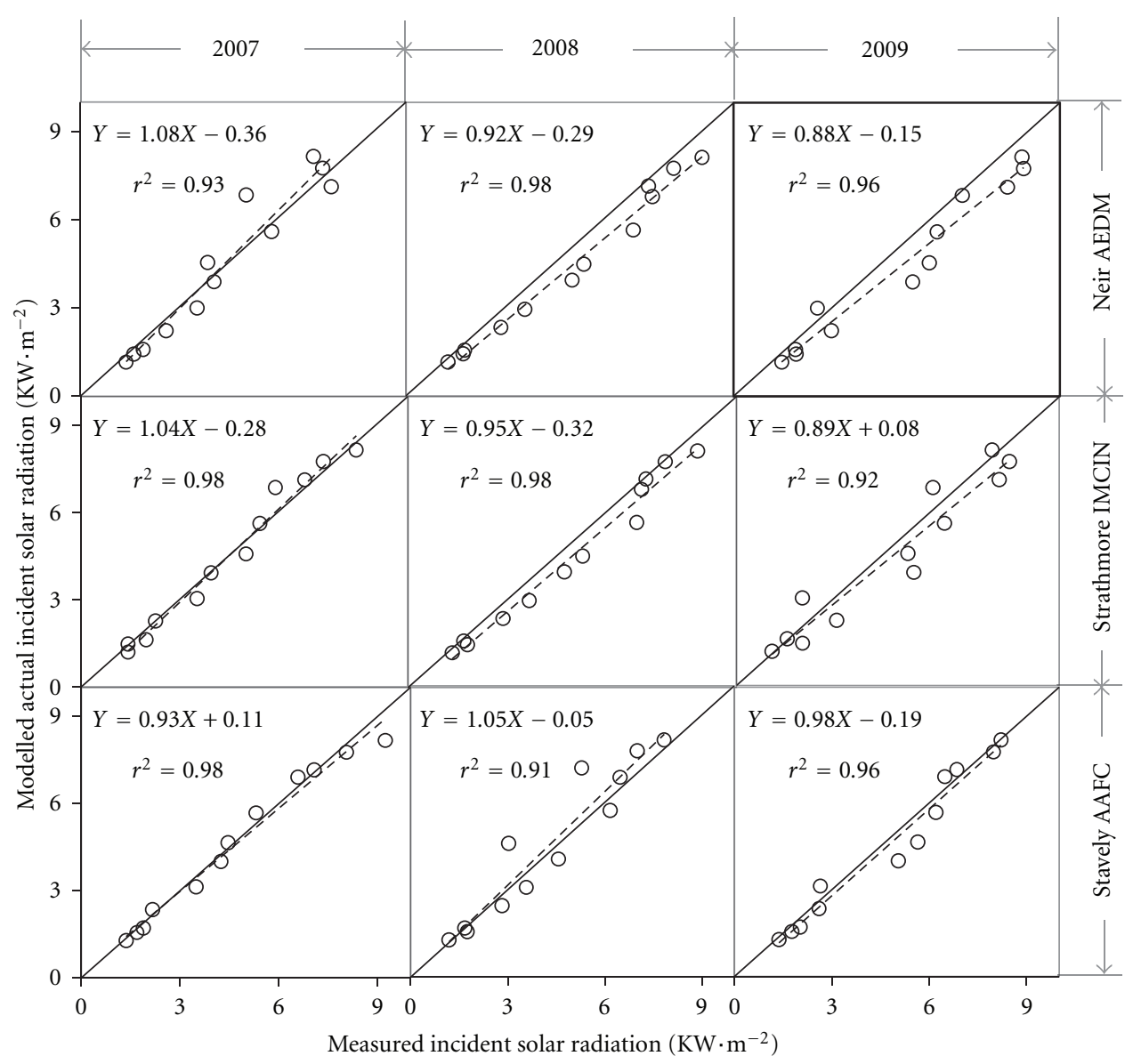

Figure 5: Relationships between measured and modelled values of the actual incident solar radiation accumulated at monthly scale at the locations of Neir AEDM, Strathmore IMCIN, and Stavely AAFC for the period of 2007-2009. The solid and dash lines represent the position of $1: 1$ and linear regression lines, respectively.
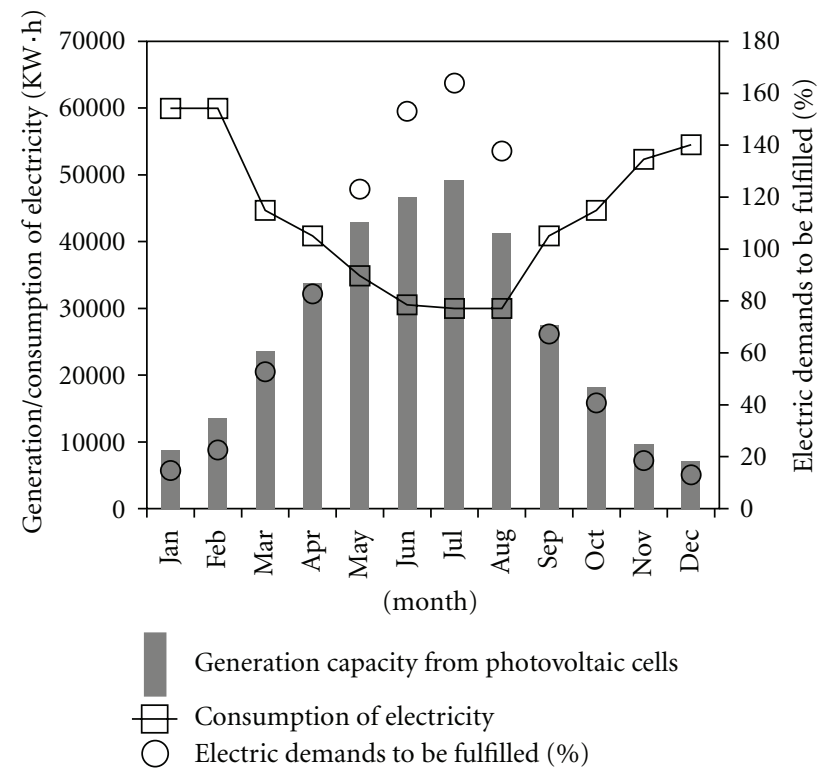

Figure 6: Monthly dynamics of "to be generated" amount of electricity from solar energy and the actual electricity consumption and the discrepancies (in the form of \%). 
(i) $100 \%$ during the period May-August, (ii) $\sim 67 \%$ and $82 \%$ during the months of September and April respectively, (iii) $\sim 40 \%$ and $52 \%$ during October and March respectively, and (iv) $\sim 13-23 \%$ during the period November-February (see Figure 6). During the cold months, it would not be possible to obtain significant amount of energy demands from solar panels (i.e., $\sim 80 \%$ ). Thus, the lack in supply could potentially be fulfilled using traditional electricity or wind energy generated in the more southern portion of Alberta.

\section{Concluding Remarks}

In this paper, we demonstrated a simple framework for modelling solar energy and its application over a portion of a residential community of Sandstone. We employed (i) daily solar radiation in calculating the actual incident solar radiation regime, and (ii) high spatial resolution remote sensing image for determining the effective roof area for installing photovoltaic cells. Our analysis revealed that the solar energy might able to support significant amount (i.e., in the range of $\sim 67-100 \%$ ) of the electrical energy needs over the community of interest during the period of AprilSeptember. These results are promising and could encourage people in harvesting solar energy to its maximum potential, which could be sustainable and clean in nature.

\section{Acknowledgments}

The authors would like to thank funding support from the University of Calgary to Dr. Hassan. The authors would also like to thank (i) Alberta Department of Agriculture and Rural Development for providing ground-based measurements of daily incident solar radiation, and (ii) Environment Canada for providing bright sunshine hours.

\section{References}

[1] REN21, Renewables 2007 Global Status Report, REN21, Paris, France; Worldwatch Institute, Washington, DC, USA, 2008.

[2] S. Solomon, D. Qin, M. Manning et al., Climate change 2007: The physical science basis. Contribution of Working Group I to the Fourth Assessment Report of the Intergovernmental Panel on Climate Change, Cambridge University Press, Cambridge, UK, 2007.

[3] S. Adelaja, J. Shaw, W. Beyea, and J. D. C. McKeown, "Renewable energy potential on brownfield sites: a case study of Michigan," Energy Policy, vol. 38, no. 11, pp. 7021-7030, 2010.

[4] H. Y. Liu and S. D. Wu, "An assessment on the planning and construction of an island renewable energy system-a case study of Kinmen Island," Renewable Energy, vol. 35, no. 12, pp. 2723-2731, 2010.

[5] A. A. Sabziparvar, "General formula for estimation of monthly mean global solar radiation in different climates on the south and north coasts of Iran," International Journal of Photoenergy, vol. 2007, Article ID 94786, 7 pages, 2007.

[6] M. S. A. Abdel-Mottaleb, F. Nüesch, and M. M. S. A. AbdelMottaleb, "Solar energy and nanomaterials for clean energy development," International Journal of Photoenergy, vol. 2009, 2 pages, 2009.
[7] C. P. A. Bourque, W. Buchanan, and Q. K. Hassan, "An ecological growth analysis of five exotic tree species intended for the commercial production of bioenergy in Jamaica," Journal of Biobased Materials and Bioenergy, vol. 3, no. 1, pp. 46-56, 2009.

[8] Q. K. Hassan, A. Ali, N. S. Sekhon, and X. Wang, "Analysis of wind power potentials at selected airport locations in Canada," International Journal of Industrial and Systems Engineering. In press.

[9] Q. Liu, Q. Miao, J. J. Liu, and W. Yang, "Solar and wind energy resources and prediction," Journal of Renewable and Sustainable Energy, vol. 1, no. 4, pp. 043105:1-043105:12, 2009.

[10] A. Woyte, R. Belmans, and J. Nijs, "Localized spectral analysis of fluctuating power generation from solar energy systems," EURASIP Journal on Advances in Signal Processing, vol. 2007, Article ID 80919, 8 pages, 2007.

[11] D. H. W. Li and T. N. T. Lam, "Determining the optimum tilt angle and orientation for solar energy collection based on measured solar radiance data," International Journal of Photoenergy, vol. 2007, Article ID 85402, 9 pages, 2007.

[12] F. Kadirgan, "Electrochemical nano-coating processes in solar energy systems," International Journal of Photoenergy, vol. 2006, Article ID 84891, 5 pages, 2006.

[13] B. K. Sovacool and C. Watts, "Going completely renewable: is it possible (let alone desirable)?" The Electricity Journal, vol. 22, no. 4, pp. 95-111, 2009.

[14] M. Z. Jacobson and M. A. Delucchi, "A path to: sustainable energy by 2030," Scientific American, vol. 301, no. 5, pp. 5865, 2009.

[15] M. Arboit, A. Mesa, A. Diblasi, J. C. Fernández Llano, and C. de Rosa, "Assessing the solar potential of low-density urban environments in Andean cities with desert climates: the case of the city of Mendoza, in Argentina," Renewable Energy, vol. 35, no. 7, part 2, pp. 1551-1558, 2010.

[16] R. Levinson, H. Akbari, M. Pomerantz, and S. Gupta, "Solar access of residential rooftops in four California cities," Solar Energy, vol. 83, no. 12, pp. 2120-2135, 2009.

[17] J. Morrissey, T. Moore, and R. E. Horne, "Affordable passive solar design in a temperate climate: an experiment in residential building orientation," Renewable Energy, vol. 36, no. 2, pp. 568-577, 2011.

[18] J. Ordóñez, E. Jadraque, J. Alegre, and G. Martínez, "Analysis of the photovoltaic solar energy capacity of residential rooftops in Andalusia (Spain)," Renewable and Sustainable Energy Reviews, vol. 14, no. 7, pp. 2122-2130, 2010.

[19] M. Qu, H. Yin, and D. H. Archer, "A solar thermal cooling and heating system for a building: experimental and model based performance analysis and design," Solar Energy, vol. 84, no. 2, pp. 166-182, 2010.

[20] R. Foster, M. Ghassemi, and A. Cota, Solar Energy: Renewable Energy and the Environment, CRC Press Taylor \& Francis Group, Boca Raton, Fla, USA, 2010.

[21] Z. Sen, Solar Energy Fundamentals and Modeling Techniques: Atmosphere, Environment, Climate Change and Renewable Energy, Springer, London, UK, 2008.

[22] Y. P. Chang, "Optimal the tilt angles for photovoltaic modules using PSO method with nonlinear time-varying evolution," Energy, vol. 35, no. 5, pp. 1954-1963, 2010.

[23] R. G. Allen, L. S. Pereira, D. Raes, and M. Smith, Crop Evapotranspiration-Guidelines for Computing Crop Water Requirements-FAO Irrigation and Drainage Paper 56, FAOFood and Agriculture Organization of the United Nations, Rome, Italy, 1998. 
[24] M. J. Ahmad and G. N. Tiwari, "Solar radiation models- a review," International Journal of Energy Research, vol. 35, no. 4, pp. 271-290, 2011.

[25] N. A. Kelly and T. L. Gibson, "Improved photovoltaic energy output for cloudy conditions with a solar tracking system," Solar Energy, vol. 83, no. 11, pp. 2092-2102, 2009.

[26] J. Ayoub and L. D. Bailey, Photovoltaic Technology Status and Prospects-Canadian Annual Report 2009, Canmet ENERGY, Natural Resources Canada, 2010.

[27] Q. K. Hassan, C. P. A. Bourque, and F. R. Meng, "Application of landsat-7 ETM+ and MODIS products in mapping seasonal accumulation of growing degree days at an enhanced resolution," Journal of Applied Remote Sensing, vol. 1, pp. 013539:1013539:10, 2007.

[28] Y. Zhang, "Understanding image fusion," Photogrammetric Engineering and Remote Sensing, vol. 70, no. 6, pp. 657-661, 2004.

[29] Q. K. Hassan, C. P. A. Bourque, and F. R. Meng, "Estimation of daytime net ecosystem $\mathrm{CO}_{2}$ exchange over balsam fir forests in eastern Canada: combining averaged tower-based flux measurements with remotely sensed MODIS data," Canadian Journal of Remote Sensing, vol. 32, no. 6, pp. 405-416, 2006.

[30] A. Angstrom, "Solar and terrestrial radiation," Quarterly Journal of the Royal Meteorological Society, vol. 50, no. 210, pp. 121-126, 1924.

[31] M. J. Barnsley, Environmental Modelling: A Practical Introduction, CRC Press, Taylor \& Francis Group, Boca Raton, Fla, USA, 2007.

[32] A. J. Gonzalez, A. Sanchez-Juarez, A. Fernandez, X. Mathew, and P. J. Sebastian, "Converting solar radiation to electric power in Mexico," in Towards a Cleaner Planet: Energy for the Future, J. Klapp, J. L. Cervantes-Cota, and J. F. C Alcala, Eds., pp. 281-303, Springer, Berlin, Germany, 2007.

[33] H. O. Menges, C. Ertekin, and M. H. Sonmete, "Evaluation of global solar radiation models for Konya, Turkey," Energy Conversion and Management, vol. 47, no. 18-19, pp. 31493173, 2006. 


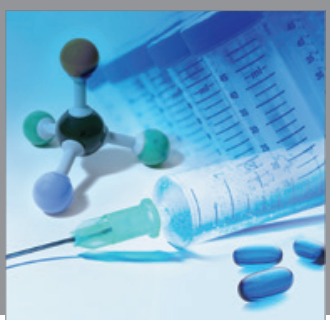

International Journal of

Medicinal Chemistry

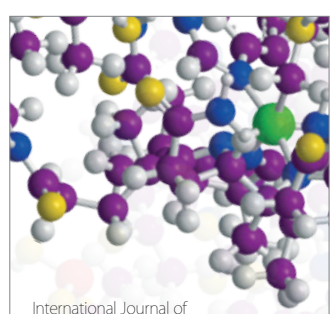

Carbohydrate Chemistry

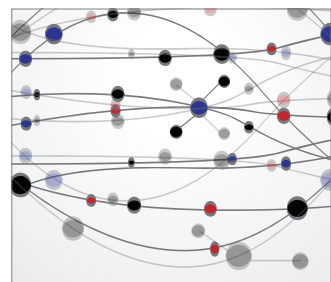

The Scientific World Journal
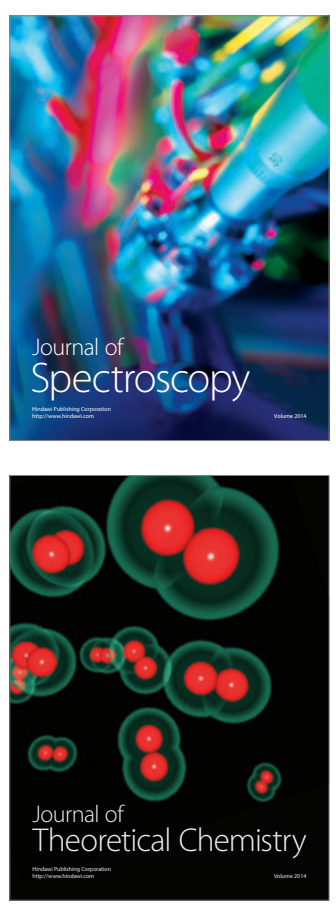
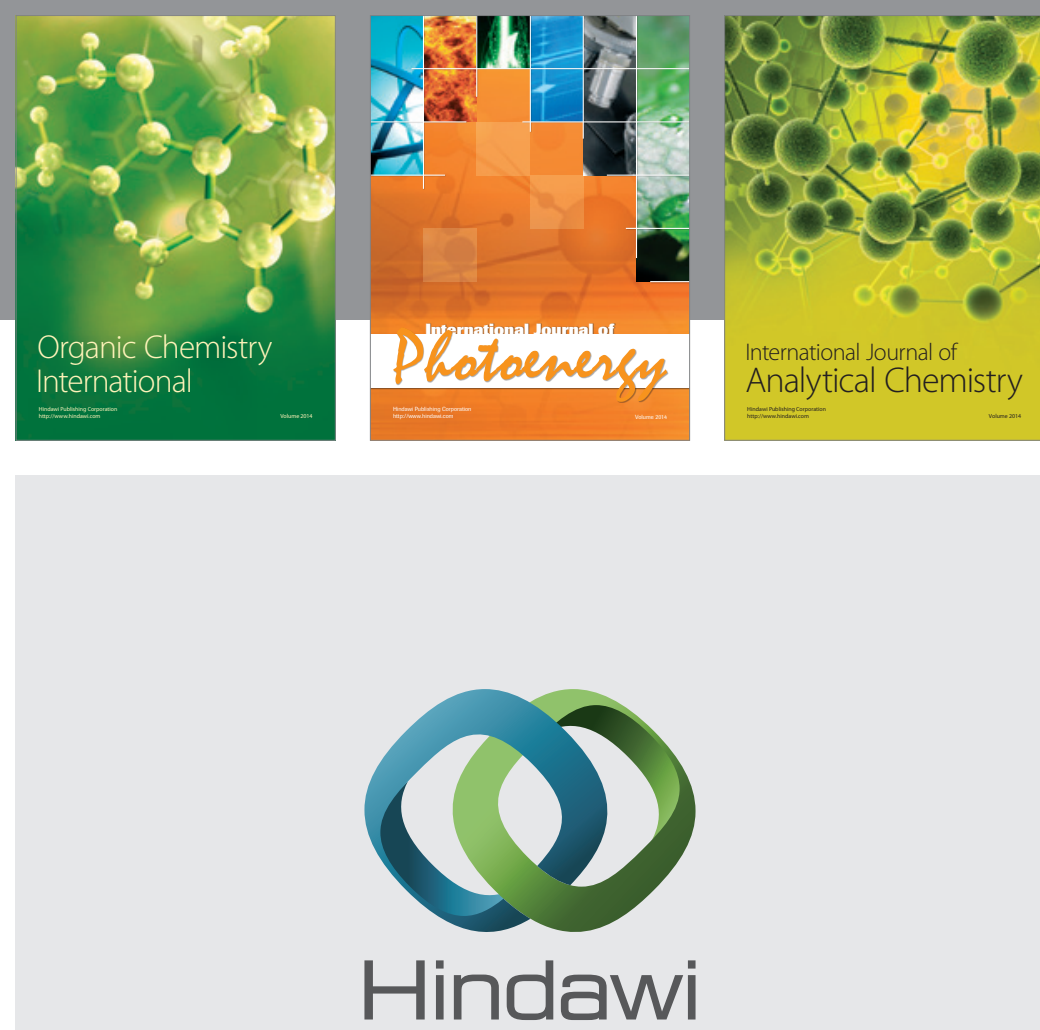

Submit your manuscripts at

http://www.hindawi.com
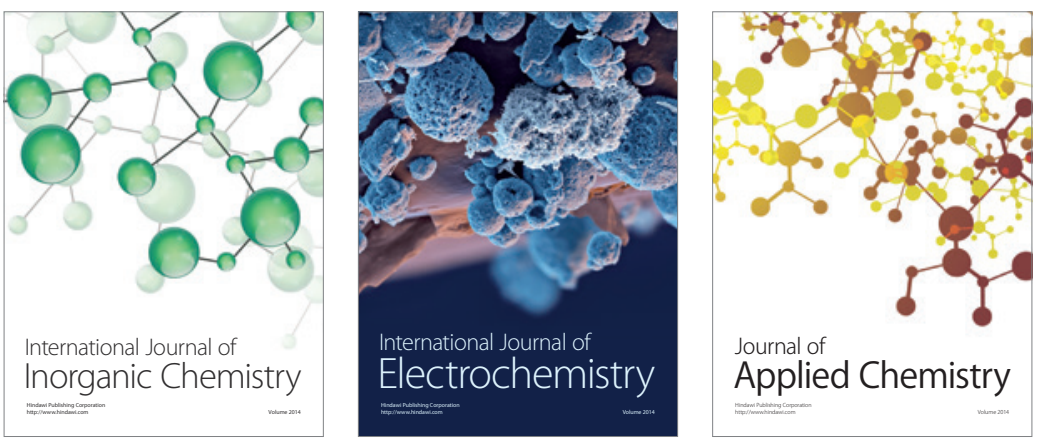

Journal of

Applied Chemistry
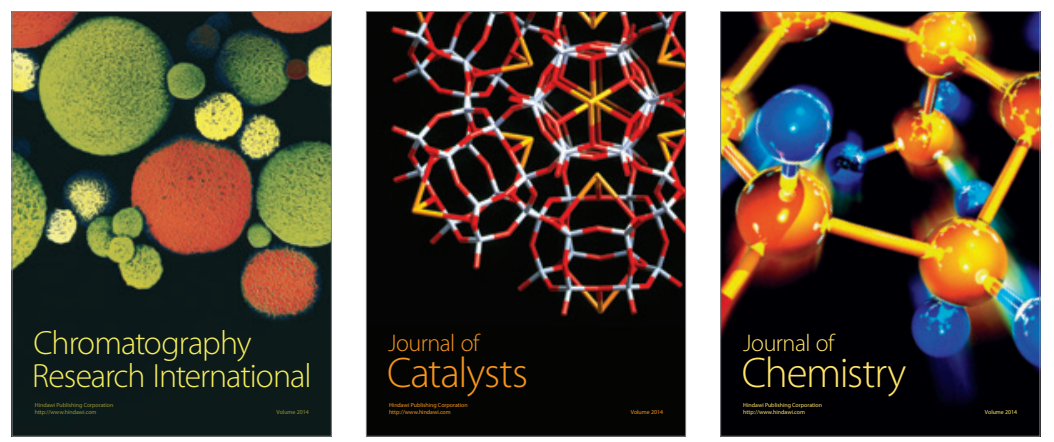
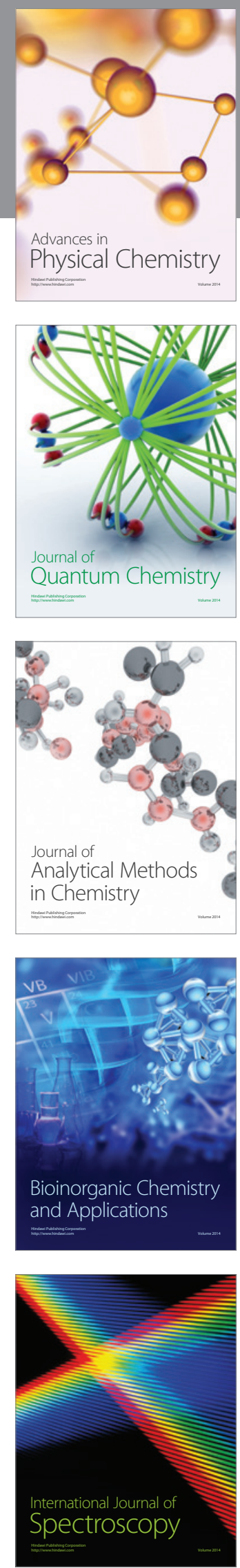